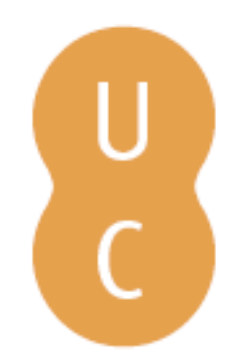

\title{
nommalina
}

\section{Forest fire risk related to the railway transport and evaluation of the effectiveness of firebreaks}

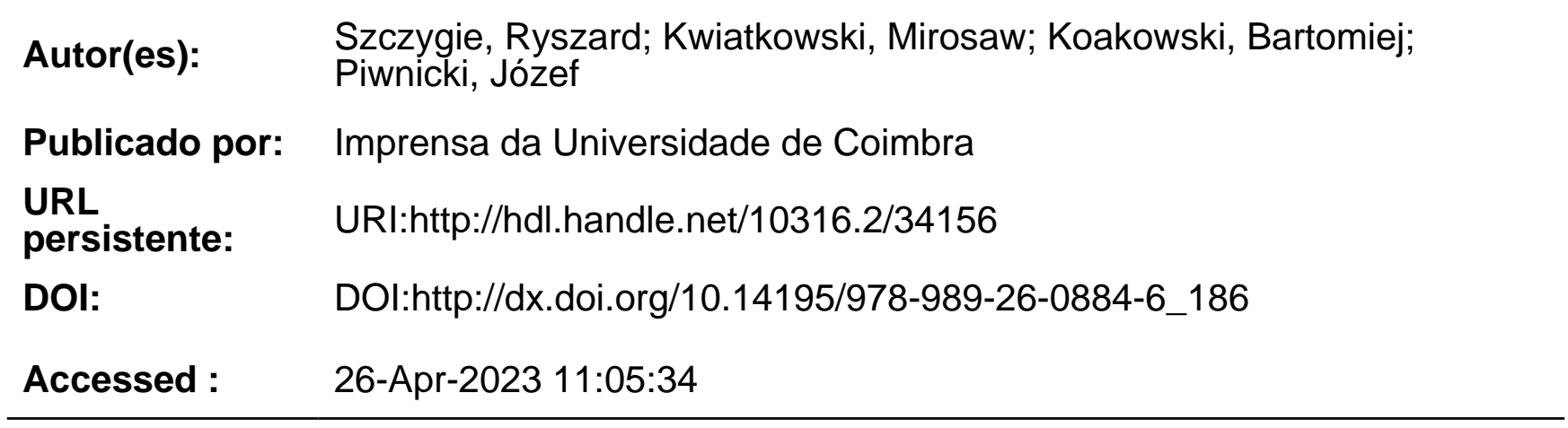

A navegação consulta e descarregamento dos títulos inseridos nas Bibliotecas Digitais UC Digitalis, UC Pombalina e UC Impactum, pressupõem a aceitação plena e sem reservas dos Termos e Condições de Uso destas Bibliotecas Digitais, disponíveis em https://digitalis.uc.pt/pt-pt/termos.

Conforme exposto nos referidos Termos e Condições de Uso, o descarregamento de títulos de acesso restrito requer uma licença válida de autorização devendo o utilizador aceder ao(s) documento(s) a partir de um endereço de IP da instituição detentora da supramencionada licença.

Ao utilizador é apenas permitido o descarregamento para uso pessoal, pelo que o emprego do(s) título(s) descarregado(s) para outro fim, designadamente comercial, carece de autorização do respetivo autor ou editor da obra.

Na medida em que todas as obras da UC Digitalis se encontram protegidas pelo Código do Direito de Autor e Direitos Conexos e demais legislação aplicável, toda a cópia, parcial ou total, deste documento, nos casos em que é legalmente admitida, deverá conter ou fazer-se acompanhar por este aviso.

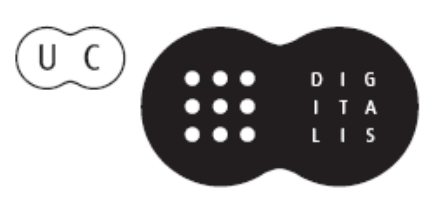




\section{ADVANCES IN}

Forest Fire

\section{RESEARCH}

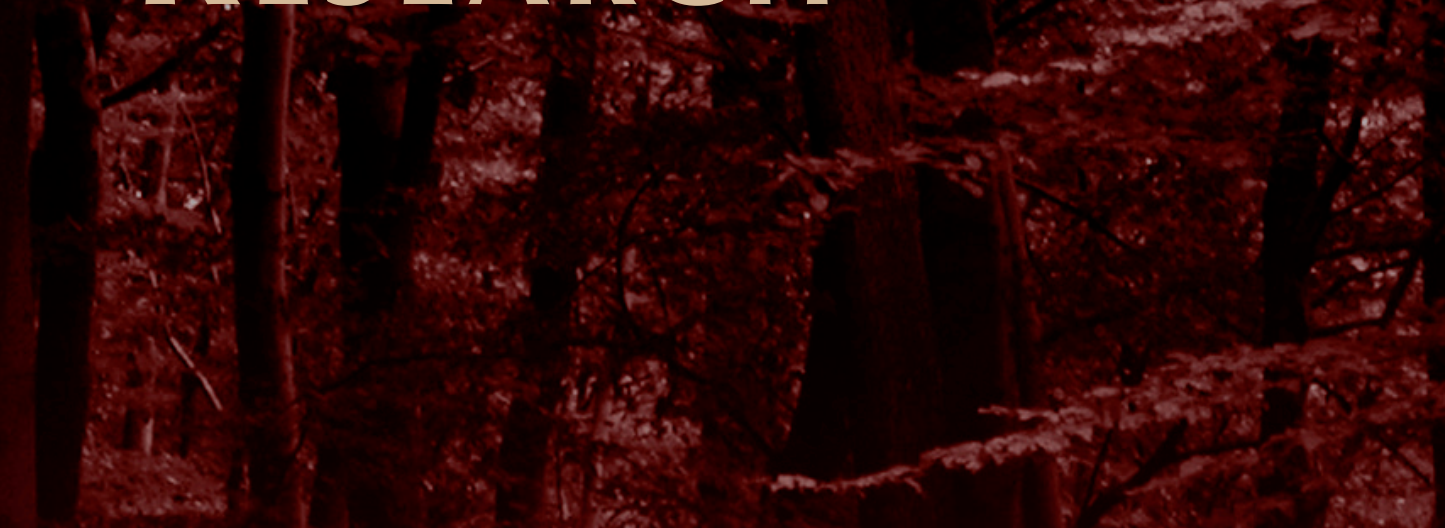

\section{DOMINGOS XAVIER VIEGAS}

\section{EDITOR}




\title{
Forest fire risk related to the railway transport and evaluation of the effectiveness of firebreaks
}

\author{
Ryszard Szczygieł, Mirosław Kwiatkowski, Bartłomiej Kołakowski, Józef Piwnicki \\ Forest Research Institute. Sękocin Stary, 3, Braci Leśnej Street, 05-090 Raszyn, Poland. \\ r.sz.czygiel@ibles.waw.pl, m.kwiatkowski@ibles.waw.pl, b.kolakowski@ibles.waw.pl, \\ j.piwnicki@ibles.waw.pl
}

\begin{abstract}
The study contains an evaluation of the occurrence of forest fires caused by rail transport and the effectiveness of the firebreaks beside railway lines. Analysis was conducted on the basis of information given in a questionnaire completed by forest administration units, inspection of the actual condition of equipment and maintenance of firebreaks and data are obtained from Polish State Railways and the State Fire Service. Analysis showed that approximately $65 \%$ of firebreaks are located in forests most subject to forest fires, $90 \%$ of firebreaks are made in pine stands, mainly of over 30 years of age $(81.8 \%)$. Most forest fires occur in coniferous forest habitats $(58.3 \%)$. Over $60 \%$ of all fires occurred in pine stands. Most frequently stands aged from 30 to 60 years $(28 \%)$. From analysis of the effectiveness of the application of firebreaks beside railway lines it is shown that the first furrow of the firebreak was crossed by $27.3 \%$ of all fires. The conduct of extinguishing operations in the case of forest fires adjacent to railway lines is significantly hindered primarily by the late discovery of the fire, difficult access and initiation of burning along a significant length. The conducted investigations indicated the necessity of making and maintaining firebreaks in order to reduce the risk of fire to adjacent forest areas, which appropriately maintained are capable of reducing the risk of fire. The accuracy of this statement is also confirmed by the fact that such a method of protection is applied in many European countries. On the basis of the analysis conducted, a modification proposal has been drawn up for the existing firebreaks also with guidelines, concerning forest fire prevention in forest areas.
\end{abstract}

Keywords: Firebreaks, forest fire risk, railway transport

\section{Introduction}

Rail transport, despite technical progress, still constitutes a significant fire risk to forest areas. It is true that over the last 30 years $^{1}$ a trend of reduction of the number of fires beside railway lines has been observed (in the years 1981-1990 rail transport was the cause of 5.92\% fires, in the years 1991-2000 $-2.1 \%$, and in the years $2001-2010-0.81 \%$ of all fires recorded), the greatest forest fire disasters occurred beside railway lines (Forest District: Rudy Raciborskie - 9060 ha and Potrzebowice - 5130 ha). Among the established causes of fires, those, which occurred because of rail transport, are seventh out of nine in statistical classification. The frequently compared cause - road transport - in the years 2001-2010 constituted the cause of $0.34 \%$ of forest fires, which is under half of the number of fires caused by rail transport.

According to the analysis of the Railway Scientific-Technical Centre ${ }^{2}$ over $90 \%$ of forest fires were caused by sparks from brake blocks, or as a result of their friction. In such a situation, where fire embers are caused, the role of passive fire protection is filled by the firebreak, executed alongside the railway line, the role of which is to prevent or limit the possibility of the spread of fire to the adjacent

\footnotetext{
${ }^{1}$ Statistical data of the Forest Research Institute

${ }^{2}$ Prevention of fires beside rail routes. Rail Scientific-Technical Centre, Warsaw 1994
} 
forest area protection. This method of fire prevention protection of forests against the risk caused by rail transport has been known since the mid-19th century and with certain modifications is currently applied also in countries other than Poland. Appropriately prepared and maintained, a belt of land is capable of preventing the spread of fire and limiting its speed and area.

Refraining from the making of firebreaks beside railway lines was the reason for undertaking the study, which was intended to assess the risk of forest fire from rail transport and the effectiveness of fire prevention protection in the form of firebreaks executed beside railway lines. The study was also required because of the lack of a complete insight concerning the cause of forest fires as a result of rail transport, concerning not only the number of fires caused and their surface area, but also fire risk development tendencies, spatial occurrence of fires in relation to firebreaks, evaluation of their effectiveness in the instance of occurrence of fire, the costs of execution and maintenance of firebreaks and also occurrence of fires in relation to habitat factors.

Obtaining reliable and complete data would provide the basis for assessment of activities, concerning protection of forests against fires and its adequacy with regard to the existing risk from rail transport and possible proposals for changes.

\section{Methods}

In the research information was used concerning the occurrence of fires beside railway lines and equipment and the maintenance of firebreaks from the State Forests, State Fire Service, Polish State Railways (PKP) and the Forest Research Institute.

The sources of this information are:

1) questionnaire information about the principles of fire prevention protection beside railway

lines in Europe and analysis of the legal situation in Poland,

2) questionnaire information from 314 forest district offices from the years 2000-2010,

3 ) information from the incident registration system of the State Fire Service (EWID), from the years 2006-2010,

4) information from Polish State Railways Polish Railway Lines (PKP PLK) from the years 2002-2011,

5) information from terrain inspections conducted in selected forest districts.

Analysis of the fire risk from rail transport and the effectiveness of firebreaks consisting of the following stages. The first analysis stage was assessment of the conditions of performance of firebreaks. It was composed of analysis of the results of questionnaires and assessment of the execution of firebreaks on site. The basis for assessment of location of firebreaks maintained beside railway lines was information obtained through research questionnaires from forestry districts in the year 2010, containing information about all firebreaks maintained beside railway lines in the territory of Poland. In this stage, inspections were made of existing methods of creating firebreaks in other European countries and in Poland. In the second stage the hypothesis was verified, that forests lying beside railway lines are subject to a greater degree of fire risk, in comparison to other forests. Verification was based on the density of occurrence of fires and the average size of single fire. For this purpose was calculated the density of occurrence of fires and the average area per single fire beside railway lines in the years 2000-2009, on the basis of data are obtained from research questionnaires. The data was compared with data concerning the remaining forests. The third stage was detailed analysis of the occurrence of fires beside railway lines conducted according to the number of fires, area burnt, causes, place of occurrence and type of fire. Because only data for fires occurring as a result of two causes (faults of means of transport - code 26, incorrect use of means of transport - code 27) is available from the information system of the State Fire Service (EWID), the analysis was performed on the basis of information from the State Forests from the years 2007-2010, which is available in the National Forest Fires Information System. The fourth stage of the analysis was the assessment of the effectiveness of 
firebreaks in the limitation of the spread of forest fires. It included the number of fires occurring in front of the first furrow of the firebreak, which crossed that furrow, the number of fires occurring between furrows, which crossed the second furrow and the number of fires that crossed both furrows. These analyses were conducted with regard to the type of forest, age of stand and prevalent species of trees.

\section{Results}

\subsection{Legal status of fire prevention protection of forests beside railway lines in Poland}

\subsubsection{Current situation in Poland}

According to statutes currently valid in Poland railway managements and hauliers and also users of rail sidings are obliged to fulfil technical and organisational conditions assuring fire prevention protection and environmental protection (art.17. point 1.3 of the Rail Transport Statute of the $28^{\text {th }}$ of March 2003 - Journal of Laws no. 16 entry 94). The principles for the execution of firebreaks beside railway lines are regulated by the Ordinance of the Minister for Internal Affairs and Administration of the $17^{\text {th }}$ June 2010 concerning the fire protection of buildings, other building structures and land areas (Journal of Laws no. 109 entry 719) and the Ordinance of the Minister of Infrastructure of the $7^{\text {th }}$ of August 2008 concerning the requirements in the extent of distance and permissible conditions of situation of trees and bushes, acoustic elements and the performance of earthworks adjacent to railway lines and also the manner of execution and maintenance of snow protection shields and firebreaks (Journal of Laws 2008 no. 153 entry 955).

According to these regulations, beside railway lines on which traffic is conducted a firebreak shall be executed in the form of two furrows of a width of at least 2 metres, at a distance from each other from 10 to $15 \mathrm{~m}$ and connected with each other every 25 to $50 \mathrm{~m}$ by transverse furrows of the same width.

\subsubsection{Protection of forests in Europe}

Analysis concerning execution of firebreaks beside railway lines in particular European countries conducted on the basis of questionnaires, which were sent to services and institutions concerned with fire prevention protection. Countries/regions, which did not declare the execution of firebreaks beside railway lines running through forested areas are: Austria, Bulgaria, the Czech Republic, Germany (landers (provinces): Baden-Wurttemberg, Bavaria, Hesse, Rhine-Westphalia), Norway, Great Britain and Sweden. Respondents justified the lack of firebreaks by the slight risk of fire in those territories. From the questionnaire it is plainly shown that in a decided majority of states the responsibility for protecting forested areas against the risk of fire caused by rail traffic is borne by the managements of railway lines. This responsibility is regulated legally or constitutes a type of agreement between railway line management and the manager of afforested land (e.g. Turkey). The costs of these measures are borne by the railway line management or are divided between the rail management and the forest management (Slovakia).

The majority of the replies obtained from representatives of German landers indicated Deutsche Bahn Ag.DB, as the entity responsible for fire prevention protection. Only in one case (MecklenburgPomerania) were the entire costs of fire prevention protection of forests borne by the private owners or managers of forests. The determining factor of the location of firebreaks is mainly the intensity of rail traffic and the susceptibility of afforested areas to the spread of fire. In the case of Switzerland and France the location of the so-called spark barriers was emphasised in places, in which trains frequently brake (downward gradients, curves), where obviously there is an increased risk of sparking from brake blocks. In Greece, Romania Portugal and in Lithuania firebreaks are executed along the entire length of rail routes running through afforested areas.

As a result of the information collected concerning methods and frequency of renewal of firebreaks, in the majority of cases they are renewed at least annually before the beginning of the fire season (April-September). Some questionnaire respondents also declared repetition of this activity in the 
autumn. The main methods of renewal of firebreaks include clearing vegetation from the specified area measured from the external edge of the tracks by mowing or application of chemicals (herbicides). Use of chemical substances in order to prepare firebreaks was emphasised in information obtained from Greece and Spain. In the countries where questionnaires were sent the assessment of the effectiveness of firebreaks was mainly specified as good and very good.

\subsubsection{Assessment of execution of firebreaks beside railway lines}

Assessment of preparation and maintenance of firebreaks based on information from 1879 enquiries. The enquiries indicated that the combined length of firebreaks in Poland amounted to $5926.6 \mathrm{~km}$, and that the decided majority of them (90.4\%) were maintained by PKP PLK. The State Forests maintained $248.1 \mathrm{~km}$ of firebreaks, and other entities maintained $322.3 \mathrm{~km}$. The majority of the land (66\%), on which the firebreaks were situated was maintained by the State Forests, $29 \%$ were the property of PKP, and the remainder $(5 \%)$ were managed by other entities. The annual cost of maintenance of firebreaks in the State Forests amounted to approximately 60,000 PLN. Whereas the Company PKP Polskie Linie Kolejowe [Polish Railway Lines] spent on average annually approximately 2,000,000 PLN, with the exclusion of the year 2011 when execution and renewal of firebreaks was limited. The results of analyses are presented in tables or directly in the text.

The results of analysis of the establishment of firebreaks along railway lines depending on the habitat type of forest are shown in table 1 . Close to $65 \%$ of firebreaks are located in forest habitats, being the most subject of fires, $90 \%$ of the firebreaks executed are in pine stands, of over 30 years old (81.8\%). Site terrain inspections, for the purpose of assessing the means and conformity with regulations for creating and maintaining firebreaks along railway lines were conducted at 67 selected locations. Among them, 46 were places where fires had occurred in the area of the railway track in 2010 . The remaining 21 inspections were made in average places for the whole length of firebreaks in forestry districts, in which a significant number of fires have occurred beside railway lines. Evaluating the distance of the first furrow from the railway embankment it is confirmed that only in $48 \%$ of cases was the distance according to the regulations. In 19\% instances the distance was less, and in 33\% greater. Conformity of distance between the furrows was confirmed in $44 \%$ of cases, in $14 \%$ the distance was less, in $42 \%$ the distance was greater. The width of furrows was confirmed in the case of the first in $84 \%$ of instances, and in the case of a second in $93 \%$ of instances. At 7 inspection locations it was confirmed that firebreaks had not been renewed for a year or maybe two years.

Table 1. Firebreaks length according to the forest habitat types

\begin{tabular}{|l|l|l|}
\hline Forest habitat type & Lenght $[\mathrm{km}]$ & Share [\%] \\
\hline BMśw & 2093,4 & 35,6 \\
\hline Bs & 20,3 & 0,3 \\
\hline Bśw & 1509,3 & 25,6 \\
\hline Bw, BMw, Bb, BMb & 297,3 & 5,0 \\
\hline L1, Ol, OlJ, Lw & 88,9 & 1,5 \\
\hline LMśw & 1146,3 & 19,4 \\
\hline LMw, LMb & 202,8 & 3,4 \\
\hline Lśw & 267,4 & 4,5 \\
\hline other & 228,9 & 3,9 \\
\hline mountain & 2,7 & 0,0 \\
\hline upland & 47,8 & 0,8 \\
\hline
\end{tabular}

\subsection{Occurrence of forest fires beside railway lines}

In the years 2000-2009 in State Forests on the belt of ground $50 \mathrm{~m}$ wide beside railway lines there were 599 fires that burnt a combined area of 350.9 ha w. In the incident registration system (EWID) the State Fire Service registered 757 fires in forests, including all forms of ownership, which occurred 
by railway lines in the years 2006-2010. Whereas according to the information of PKP Polskie Linie Kolejowe S.A. in the years 2002-2011 28 fires were noted involving an area of 84.19 ha. The information obtained from PKP PLK is grossly disproportionate to the information provided by the State Forests and the State Fire Service. The discrepancy probably results from internal instructions of PKP, that only incidents of fires that constitute a significant threat and the existence of which might be a liability to PKP PLK are recorded. With regard to the completeness of information, further analysis was conducted on the basis of information obtained from the State Forests. In order to verify the hypothesis stating that forests lying beside railway lines are at a greater risk of fire than the remaining afforested areas, the density of occurrence of fires was calculated and also their average surface area with regard to the category of forest fire threat (kzpl). The results shown in table 2 indicate that the density of occurrence of fires beside railway tracks (2.0 fires /1000 ha) was almost threefold greater in comparison to forests classified as I and II kzpl (0.7 fires/1000 ha).

Table 2. Density of forest fires occurrence and average burnt area in the relation to localization of the forest fire

\begin{tabular}{|c|c|c|c|}
\hline \multirow{2}{*}{$\begin{array}{c}\text { Place of the fire occurrence } \\
\text { I and II forest fire risk category } \\
\text { (kzpl) }\end{array}$} & $\begin{array}{c}\text { Forest fire } \\
\text { risk category }\end{array}$ & $\begin{array}{c}\text { Average annual density of the } \\
\text { fire occurrence [ fires/1000 ha] }\end{array}$ & $\begin{array}{c}\text { Average burnt } \\
\text { area [ha] }\end{array}$ \\
\cline { 2 - 4 } & I & 1,1 & 0,28 \\
\cline { 2 - 4 } & II & 0,3 & 0,32 \\
\hline \multirow{2}{*}{$\begin{array}{l}\text { I i II } \\
\text { Forests area along the railway }\end{array}$} & I & 0,7 & 0,31 \\
\cline { 2 - 4 } & II & 2,5 & 0,65 \\
\cline { 2 - 4 } & I i II & 1,3 & 0,41 \\
\hline
\end{tabular}

Comparing individual density in particular categories of fire risk it is shown that in afforested areas I kzpl is over twice as great in comparison to the remaining areas included in this category. Whereas in areas II kzpl this difference is over four times as great. The density of occurrence of fires beside railway lines in areas classified as I kzpl was almost twice as great as that of areas classified as II kzpl. Evaluating the average area of single fire and for forests lying beside railway lines in comparison to the remaining forests classified as I and II kzpl it may be seen, that beside railway lines it is almost twofold greater.

\subsection{The occurrence of forest fires beside railway lines in relation to stand conditions and the size of the burnt area.}

Analysis of the occurrence of fires beside railway lines in relation to forest habitat type is shown in table 3.

Table 3. Number of forest fires along the railway in the relation to the forest habitat type

\begin{tabular}{|l|c|c|c|c|c|c|}
\hline \multirow{2}{*}{ Forest habitat type } & \multicolumn{2}{|c|}{ Total forest fire } & \multicolumn{2}{c|}{ Ground cover forest fire } & \multicolumn{2}{c|}{ Together } \\
\cline { 2 - 7 } & number & share[\%] & number & share[\%] & number & share[\%] \\
\hline BMśw & 38 & 50,0 & 139 & 26,9 & 177 & 29,8 \\
\hline Bs & & & 3 & 0,6 & 3 & 0,5 \\
\hline Bśw & 12 & 15,8 & 122 & 23,6 & 134 & 22,6 \\
\hline Bw,BMw,Bb,BMb & 6 & 7,9 & 26 & 5,0 & 32 & 5,4 \\
\hline L1, Ol, OIJ, Lw & 2 & 2,6 & 10 & 2,0 & 12 & 2,0 \\
\hline LMśw & 10 & 13,1 & 76 & 14,7 & 86 & 14,5 \\
\hline LMw, LMb & 4 & 5,3 & 8 & 1,5 & 12 & 2,0 \\
\hline Lśw & 3 & 4,0 & 14 & 2,7 & 17 & 2,9 \\
\hline undefined & & & 116 & 22,7 & 116 & 19,6 \\
\hline upland & 1 & 1,3 & 3 & 0,6 & 4 & 0,7 \\
\hline
\end{tabular}


Most forest fires occurred in forest habitats (58.3\%), including fresh mixed coniferous forest (BMśw) $29.5 \%$ and fresh coniferous forest (Bśw) $22.6 \%$. 21.4\% of fires occurred in forest habitats, including fresh mixed broadleaved forest (LMśw) $14.5 \%$. There is a lack of clear difference of combined number of forest fires between stand age categories. Most fires (28\%) occurred in stands aged from 30 to 60 years. Over $60 \%$ of all fires occurred in pine stands, and next (at a similar level) in stands, in which the principal species were birch and oak. Information presented in the above tables enables one to state that the flammability of forests beside railway lines is typified with a certain variability in comparison to the remaining forests. Apart from "particularly flammable" (Bs, Bśw, BMśw) attention is drawn to the significant flammability of stands growing in moist and boggy habitats (Bw, BMw, Bb, BMb, Lt, $\mathrm{Ol}, \mathrm{OlJ}, \mathrm{Lw}$ ), which may arise from the presence on track side shoulders of a strongly developed grass cover, which during times of drought and in spring-autumn periods constitutes a high fire risk.

\section{Size of burnt area}

Analysis conducted on 553 fires since the remaining 46 fires did not spread to the forests, including within its reach exclusively the tracks and therefore omitted. Most fires were germinal, the area of which did not exceed 0.05 ha, and then small (from 0.06 do 1 ha). With regard to percentage share by size of fires occurring in all forests the results were similar. This however does not apply to large fires (from 10.1 to $100 \mathrm{ha}$ ), $1.6 \%$ of which occurred beside railway lines, and only $0.1 \%$ in remaining forests. This indicates that the probability of occurrence of a large fire beside a railway track is significantly greater.

The most frequent cause of forest fires according to information from the National Forest Fires Information System was rail transport, which caused 39.9\% of all fires. Next in order were: arson $(7.3 \%)$, carelessness of adults (5.2\%), spread of fire from non-forested areas (1.6\%) and electric power line malfunction and carelessness of children accounting for $0.5 \%$. It was not possible to establish the cause in the case of $44.6 \%$ of all fires. Quite different information is given by PKP PLK, according to which arson is the dominant cause (39.3\%), and followed by: blocked brake blocks $(21.4 \%)$, sparks from locomotive funnel, electrical equipment faults and starting fire from train at 3.6\%. Fires for which no cause was established constituted $28.5 \%$.

\subsection{Assessment of the effectiveness of firebreaks in limiting the spread of fires in forest}

Analysis of the effectiveness of firebreaks along railway tracks in the limitation of the spread of fires was conducted on the basis of questionnaire concerning 417 forest fires in.

In the assessment were considered:

- the number of fires occurring in front of the first furrow, which crossed that furrow,

- the number of fires which crossed both furrows,

- the number of fires occurring between furrows, which crossed the second furrow.

Results with regard to stand conditions are shown in tables 4-6. 
Table 4. Number of forest fires occurred before the first firebreak furrow and which crossed the first firebreak furrow according to the forest habitat type

\begin{tabular}{|c|c|c|c|}
\hline Forest habitat type & $\begin{array}{c}\text { Number of fires which crossed the first } \\
\text { firebreak furrow }\end{array}$ & $\begin{array}{c}\text { Total number of } \\
\text { fires }\end{array}$ & Share[\%] \\
\hline BMśw & 33 & 112 & 29,5 \\
\hline Bs & 2 & 2 & 100,0 \\
\hline Bśw & 30 & 96 & 31,3 \\
\hline Bw, BMw, Bb, BMb & 15 & 20 & 75,0 \\
\hline Lt, Ol, OlJ, Lw & 5 & 10 & 50,0 \\
\hline LMśw & 14 & 55 & 25,5 \\
\hline LMw, LMb & 3 & 9 & 33,3 \\
\hline Lśw & 4 & 9 & 44,4 \\
\hline undefined & 5 & 95 & 5,3 \\
\hline mixed & 2 & 7 & 28,6 \\
\hline upland & 1 & 2 & 50,0 \\
\hline together & 114 & 417 & 27,3 \\
\hline
\end{tabular}

Presented in table 4 information confirming significantly greater threat to forests by fires, in more fertile and moist habitats. They are places, in which on nonforested areas an abundant grass cover growth may occur and certainly for that reason a greater number of fires crossed the first furrow. Analysing the effectiveness of limiting the spread of fire by the first furrow in relation to the age of the stand it may be stated that its effectiveness increases together with the age of the stand. However similarly to the assessment conducted with regard to habitat type of forest is the situation in the case of prevailing species. From the data analysed it is shown that the first furrow was crossed by $27.3 \%$ of all fires.

The next aspect of information analysis was the assessment of effectiveness of the first furrow depending on the place of occurrence of fire (table 5).

Table 5. Number of forest fires occurred before the first firebreak furrow and which crossed the first firebreak furrow according to the place of the fire outbreak

\begin{tabular}{|c|c|c|c|}
\hline Place of the fire outbreak & $\begin{array}{c}\text { Number of fires which } \\
\text { crossed the first firebreak } \\
\text { furrow }\end{array}$ & $\begin{array}{c}\text { Total number } \\
\text { of fires }\end{array}$ & Share[\%] \\
\hline $\begin{array}{c}\text { Between railway and the edge of } \\
\text { embankment or ditch }\end{array}$ & 68 & 227 & 30,0 \\
\hline $\begin{array}{c}\text { Between the edge of embankment or } \\
\text { ditch and first firebreak furrow }\end{array}$ & 46 & 190 & 24,2 \\
\hline
\end{tabular}

Approximately $6 \%$ more was the number of fires, which crossed the first furrow in the case of fires, which occurred within the vicinity of a railway line (to the edge of embankment or ditch) in comparison to the fires, which occurred from the edge of embankment or ditch to the first furrow. This probably results from the time of free spread of these first fires until the moment of reaching the first furrow was longer, and because of that attained a greater intensity, which facilitated overcoming obstacles. In the case of fires, which crossed both furrows, the analysis included fires occurring in front of the first furrow, which crossed this furrow and analysis of what proportion of them cross the second furrow - table 6. Of the fires, which crossed the first furrow $22.8 \%$ also spread beyond the second furrow. The spread of fires, which occurred in more fertile, though moist habitats in deciduous stands, was 
significantly more effectively stopped by the second furrow than by the first furrow. This is probably connected with the significantly weaker spread of herbaceous soil cover inside the stand in comparison to the sunlit part in front of the first furrow. Investigating the age of the main stand the least fires crossed the second furrow in stands with an age of 30-60 years.

Table 6. Number of forest fires occurred before the first firebreak furrow and which crossed the second firebreak furrow according to forest habitat type

\begin{tabular}{|l|c|c|c|}
\hline Forest habitat type & $\begin{array}{l}\text { Number of fires which } \\
\text { crossed the second } \\
\text { firebreak furrow }\end{array}$ & $\begin{array}{l}\text { Total } \\
\text { number } \\
\text { of fires }\end{array}$ & Share[\%] \\
\hline BMśw & 6 & 33 & 18,2 \\
\hline Bs & 10 & 2 & \\
\hline Bśw & 5 & 30 & 33,3 \\
\hline $\begin{array}{l}\text { Bw, BMw, Bb, } \\
\text { BMb }\end{array}$ & & 15 & 33,3 \\
\hline Lł, Ol, OlJ, Lw & 1 & 5 & \\
\hline LMśw & 1 & 14 & 7,1 \\
\hline LMw, LMb & 2 & 3 & 33,3 \\
\hline Lśw & & 4 & 50,0 \\
\hline undefined & 1 & 5 & \\
\hline mixed & 26 & 2 & 50,0 \\
\hline upland & & 1 & \\
\hline together & & 114 & 22,8 \\
\hline
\end{tabular}

According to questionnaire data only 98 fires occurred between furrows, and only 1 fire, which occurred in a pine stand aged $>60$ growing in a BMśw (fresh mixed coniferous forest habitat) crossed the second furrow, which constituted $3.8 \%$ of all analysed occurrences. Attention should be drawn to the fact that the conduct of fire extinguishing operations in the case of forest fires by railway lines is significantly hindered primarily by late discovery of fire, impeded access and initiation of burning along significant distance. From reports in the EWID State Fire Service system it is shown that burning on a section from 100 to $500 \mathrm{~m}$ occurred in $5.4 \%$ of all occurrences, on a section from 500 to $1000 \mathrm{~m}$ in $2.1 \%$, and $7.3 \%$ of incidents were noted when the section was longer than $1000 \mathrm{~m}$.

\section{Summary}

The conducted research showed the necessity of creating firebreaks beside railway lines, which appropriately maintained are capable of reducing the fire risk to adjacent areas of forest areas. The correctness of this statement is equally confirmed by the fact of the application of such a means of protection in many European countries. Also in those, in which the rail rolling stock used is significantly more modern than in Poland and creates less fire risk. In the majority of states in which firebreaks are executed beside railway lines, they have a mineralised form, or vegetation free belts of a width from 2 to $20 \mathrm{~m}$. The factor, which is considered in making the decision of location of firebreak, is primarily the density of rail traffic, the level of risk and the susceptibility of afforested terrain to fire. Firebreaks are renewed at least once a year prior to the forest flammability season, by removal of vegetation by mowing or by application of chemical substances.

Considering the research results, from which it is shown that approximately $54 \%$ of forest fires beside railway lines occurred in front of the first firebreak furrow and of these fires almost $27 \%$ crossed this belt, drawing up a modification of the means of executing firebreaks one is guided primarily by the need to halt or limit the spread of fire of relatively low burning intensity. This may be achieved, if the 
barrier belt shall be situated as close as possible to the railway line, thereby limiting the time of unimpeded fire development of fire, fire loading shall be reduced and a mineralised belt shall be wider. For these reasons the proposed firebreaks beside railway lines should have the form of one mineralised belt of a width of a least $4 \mathrm{~m}$ placed as close as possible to the line (Fig.1). Additionally it is recommended that the belt section be extended to public or fire access road executed in such a way that it might simultaneously fulfil such a role. Firebreaks should be situated in forests, through which railway lines pass and that are classified as having I and II category fire risk.

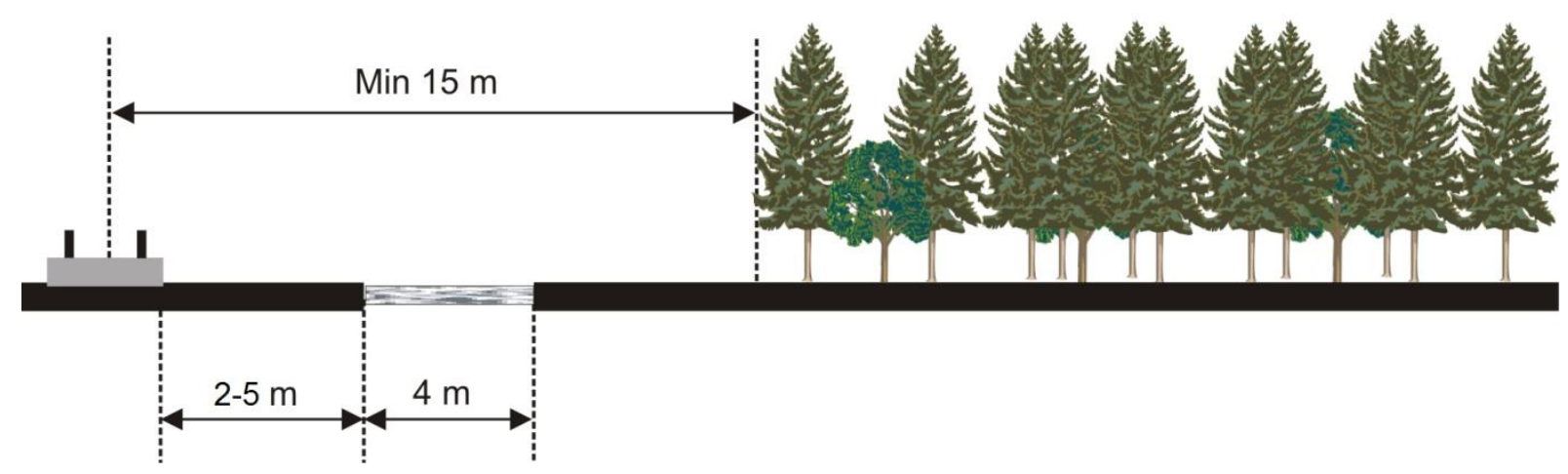

Figure 1. Scheme of the modified firebreak beside the railway

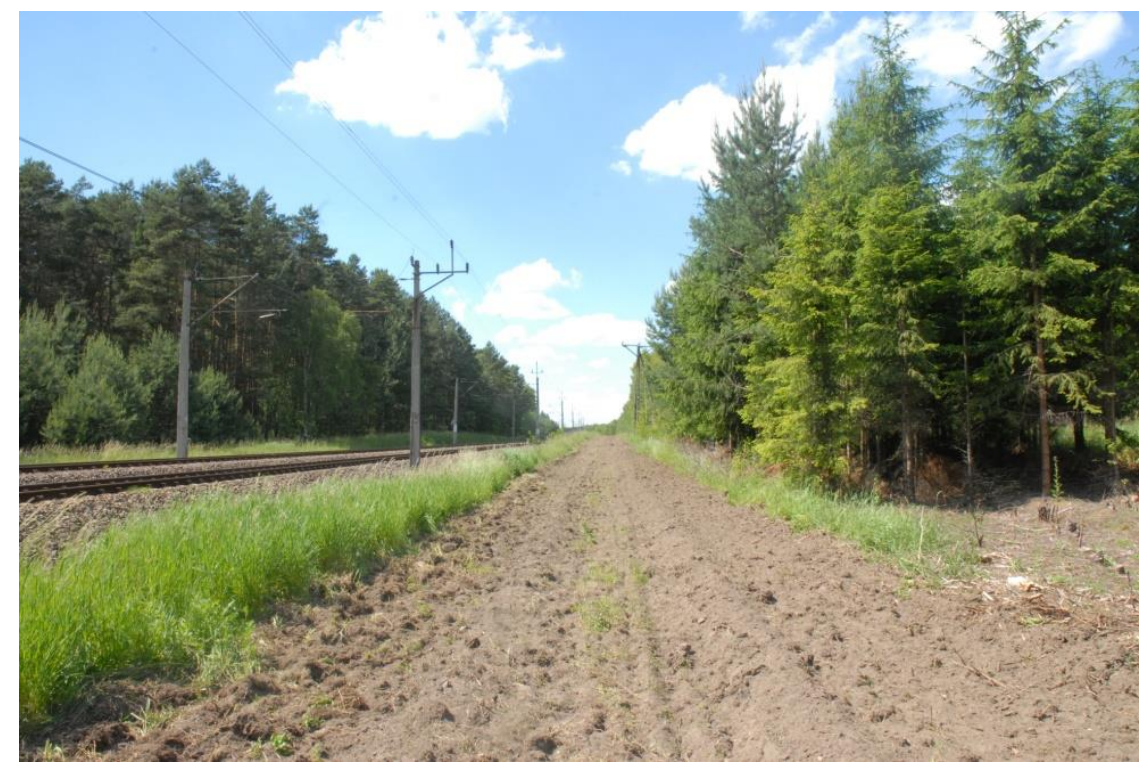

Figure 2. Modified firebreak beside the railway

In the case of modernisation of existing firebreaks it is recommended to use the existing first furrow, executing widening of this furrow to the required width from the side of the tracks, as the ground conditions permit. In connection with the above it has become essential to change the regulations currently in force through agreement of the ministers responsible for supervision of rail traffic, forests and fire prevention protection.

The amendment of the regulation became legally valid through the Ordinance of the Minister of Transport, Building and Marine Economy of 15 March 2013. 

Abbreviation:
BMśw - fresh mixed coniferous forest
Bs - dry coniferous forest
Bśw - fresh coniferous forest
Bw - moist coniferous forest
$\mathbf{B M w}$ - moist mixed coniferous forest
$\mathbf{B b}$ - bog coniferous forest
$\mathbf{B M b}$ - bog mixed coniferous forest
$\mathbf{L l}$ - riparian forest
$\mathbf{O l}$ - alder forest
OlJ - alder-ash forest
$\mathbf{L w}$ - moist broadleaved forest
LMśw - fresh mixed broadleaved forest
$\mathbf{L M w}$ - moist mixed broadleaved forest
$\mathbf{L M b}$ - bog mixed broadleaved forest
Lśw - fresh broadleaved forest

\section{References}

Prevention of fires beside railway routes. Railway Scientific-Technical Centre, Warsaw 1994 